\section{Higher Education, Resistance, and State Building in Palestine}

\section{Lisa Taraki}

Lisa Taraki is associate professor of sociology in the Department of Sociology and Anthropology, Birzeit University, Palestine. Address: Department of Sociology and Anthropology, Birzeit University, Birzeit, West Bank, Palestine.E-mail: <ltaraki@planet.edu>

$\mathrm{T}$ he extension of the higher education "franchise" to significant numbers of young people with modest means and from underprivileged strata since the mid-1970s has had far-reaching social and political consequences for Palestinian society. This brief article will investigate how Palestinian institutions of higher education-primarily the four universities in the West Bank and Gaza Strip-were implicated in the formation of an influential and hegemonic generation of activist intelligentsia in the crucial two decades preceding the establishment of the Palestinian $\mathrm{Au}-$ thority. It will also discuss this generation's fortunes under the current social and political regime in Palestine.

It is appropriate to locate the widening of opportunities for higher education in the mid-1970s within the general trajectory taken by the Palestinian national movement during the same period. It may be noted briefly that changes in the strategic thinking of the Palestine Liberation Organization (PLO) after 1974 identified the Occupied Territories as the site of the future Palestinian state and the main arena for the struggle for its realization. Thus, the establishment of an infrastructure of national institutions as well as a network of political parties and front organizations to promote the struggle can be viewed as the cornerstones of the Palestinian state-building strategy. The few institutions of higher education existing in the Occupied Territories were thus "nationalized," and their rapid expansion after the mid-1970s was supported by funds channeled by the PLO into the Occupied Territories.

Wide sectors of society took advantage of this unprecedented availability of highly subsidized "mass" university education, and enrollment in local institutions of higher education rose dramatically during the 1970s and 1980s. Although the PLO and some political parties were instrumental in providing university education in the Arab world and abroad (mainly through scholarships offered by some Arab and then-socialist countries), the bulk of university graduates in the Occupied Territories after the 1970s have been the products of the local educational system.

Palestinian universities during the latter part of the 1970s and throughout the 1980s were the prime site for the formation of a cadre of political activists who at important junctures were in the vanguard of the national resistance to occupation. While such cadres were also being recruited and built within other institutions such as sec- ondary schools, labor unions, and women's organizations, the universities were by far the most enabling medium for the crystallization of a politicized cohort of activists.

Higher education has been perceived as, and has actually been, an avenue of social mobility for sons and daughters of peasants, refugees, and the urban middle and lower classes in Palestinian society. In this sense, graduates of local universities constitute a significant segment of the growing middle strata in Palestinian society, especially in the period after the establishment of the Palestinian Authority and the expansion of employment opportunities in the growing public and private sectors. What concerns us here, however, is how Palestinian universities were implicated in this process by constituting the environment par excellence for the elaboration of a politically hegemonic elite during the period prior to and after the establishment of the Palestinian Authority.

The "nationalization" of the universities during this critical period meant above all that - by virtue of the fact that they were being supported by public, national funds (through the Palestinian Council for Higher Education) they were part of the national project. As such, their administrations were expected (and often compelled) to allow full freedom of political activity and to align their institutions with the national movement. While political activity was largely conceived of as national, anti-occupation resistance, there was at the same time an increased student focus on internal university politics, embodied in activities such as the campaign for "Arabization" of the curriculum and the struggle for student representation in university bodies. Elected student councils succeeded in wresting a considerable degree of authority (and recognition of the legitimacy of that authority) from university administrations and became a powerful force in university life.

Palestinian universities during the latter part of the 1970s and throughout the 1980s were the prime site for the formation of a cadre of political activists.

The activist student elite we refer to here is largely of peasant, refugee, or middle-to-poor urban origins. During the late 1970s and the crucial decade of the 1980s, these young men (and a very few women) constituted the leadership of the student movement and acquired unprecedented influence in a highly politicized environment that valorized activism and commitment to the national struggle. Most, if not all, of these young men had been 
imprisoned for varying periods of time and thus rose to leadership positions within their respective political organizations (of which the student groups at the universities may be considered front organizations). By the end of the 1980s, many of the top-ranking leaders of the popular uprising were individuals who had been student activists at Palestinian universities.

The far-reaching political and social transformations put in motion by the establishment of the first Palestinian authority on Palestinian territory in 1994 have had different implications for the political elite under discussion. While the fortunes of one of its components have risen considerably, the fate of the others is not as immediately obvious.

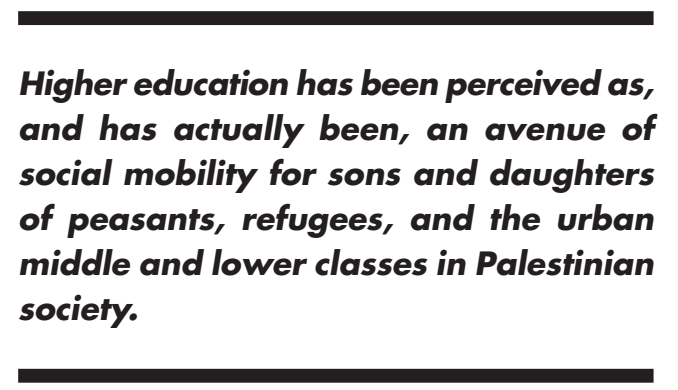

One of the notable features of the Palestinian political system today is its virtual control by the "ruling party," the Fatah movement. For the generation of Fatah student leaders formed in the critical two decades preceding the establishment of the Palestinian Authority, this has meant enhanced influence and social advancement within the ranks of the "state" bureaucracy in formation. Middle-level (and a few high-level and high-profile) posts in Palestinian National Authority institutions are staffed by former student activists of the Fatah movement; their placement in the various security apparatuses is also a striking feature of the current political landscape.

Former leaders of the left student organizations have had a different experience. Faced with the erosion of a sizable portion of their organizations' popular social base, they have pursued two principal avenues for employment and advancement. One has been employment within the expanding public sector, which has been viewed by some observers as a process of co-optation — an effort by the ruling party to neutralize a potential opposition. The other avenue pursued by the more resourceful has been in the growing body of nongovernmental organizations, in which many have found employment opportunities and some leadership positions. It remains to be seen whether these frustrated political careers will find new outlets under the new regime in the form of new parties, or in rejuvenated PLO factions turned opposition parties.

\section{The University Education of Syrian Engineers}

\section{Sari Hanafi}

Sari Hanafi is Senior Researcher at the Centre d'Études et de Documentation Économique, Juridique et Sociale (CEDEJ) in Cairo. Address: CEDEJ, POB 392, Muhammed Farid, Cairo, Egypt. E-mail: <sari@idscl.gov.eg>.

$\mathrm{T}$ his article examines instruction and learning at the university-level in Syria pertaining to the training of civil engineers. The material presented is drawn from data collected in the early 1990s in the course of research for my doctoral dissertation.

\section{French and Syrian Curricula}

The above study compared the training of civil engineers in Syria and in France in two institutional settings-Damascus University and the ENSAIS (Ecole nationale supérieure des arts et industries de Strasbourg). The data reported below relate to Damascus University. It is striking that while curricula are similar in both institutions (with the exception of computer sciences and law and, to a certain extent, the technology of construction), instructional methods differ in two major respects:

- The instruction is based on theoretical training. It is characterized by the virtual absence of vocational or technical education. Appropriate laboratory facilities are either unavailable or underutilized. The university does not maintain ties with either the public or private sector. As a result, students do not have opportunities for practical training.

- Some 85 percent of the lecturers did not assign their students any readings from the professional literature and confined their teaching to the lecture format. Only a minority of them encouraged students to look at issues outside the classroom. This state of affairs is largely a consequence of policies of Arabization and problems related to the inadequate availability of Arabic textbooks.

\section{Politics of Arabization}

University textbooks are often translated into Arabic without any mention of the original source and without any bibliographical references. In fact, producing textbooks for the university is part of the extensive policies of Arabization. Although Syria often boasts at regional and Arabic conferences of its capacity to provide "Arabized" sciences, in engineering the science produced shows mixed results at best and in some cases disastrous outcomes.

Arabization aims to make knowledge accessible to all strata of the population, not just to small a "colonial" elite. 